\title{
Teachers' Values: \\ An International Study of What Sustains a Fulfilling Life in Education
}

\author{
Jonathan M Barnes \\ Correspondence: Jonathan M Barnes, Visiting Senior Research Fellow, Canterbury Christ Church University, United \\ Kingdom.
}

Received: February 18, 2019

doi:10.11114/jets.v7i5.4151

\author{
Accepted: March 11, $2019 \quad$ Online Published: March 19, 2019 \\ URL: https://doi.org/10.11114/jets.v7i5.4151
}

\begin{abstract}
The recruitment and retention 'crises' in US and UK teaching have major and negative implications for the future of education. This pilot study uses extended conversations with Asian and African teaching staff to examine the role of values in helping teachers sustain positive contributions to children's lives and world. In five elementary schools, the researcher asked: What is the role of personal values in recruiting, retaining, sustaining and building the creative capacity of teachers? The study found that a close alignment of institutional and individual values generated strong positive impacts on teacher fulfillment and resilience. It further suggests that by using their own autobiographical 'values-stories', teachers could advance personal values and build their capacity to contribute. The article proposes implications for all education departments, universities and schools seeking to address declining rates of teacher recruitment and retention. Recommendations include greater attention to the values that bring individuals to education, a steer towards using values-stories across the curriculum and a focus on 'Big Issues' in Initial Teacher Education.
\end{abstract}

Keywords: values, teachers, stories, well-being, retention, recruitment, schools, curriculum

\section{Introduction}

Our choices are rarely random. Decisions about jobs, partners, holidays or breakfast cereal are guided by the values we hold. Values - fundamental beliefs that direct our thinking and are demonstrated in our lives through action - differ from ideals - virtuous ideas sympathised with, but not necessarily acted upon. Values are not always virtuous - Hitler and Pol Pot had very strong values. Often captured in single words, values may be egocentric, chauvinistic or nationalistic; they may also be inclusive and humanitarian, seeking conditions like justice, love, security, beauty, community, equality, rights or sustainable living.

Values shape identity. They vary widely between us, but often overlap within sub-cultures, families and friendship groups, (Boski, Stus and Tiaga, 2004). They frequently have an early genesis. Previous research has suggested that in teachers most values were formed (or retrospectively acknowledged), during childhood - typically between 7 and mid-teenage (Barnes, 2013).

Our sense of well-being is influenced by values. When they are obstructed, conflicted, challenged, dismissed or suppressed we feel unhappy, unfulfilled, even despairing (Frankl, 1992). Happiness is argued to ensue when personal values are acknowledged, accommodated, elevated or affirmed. Subjective and value-rich positive states like satisfaction, fulfillment or higher purpose feature regularly in definitions of social, physical and psychological health (see Seligman, 2011; Diener et al. 2010; Ryff, 1989) though others (for example, Miller, 2008) argue such conditions simply describe a particular, ambitious and outgoing personality type. The link between the humble and inclusive values encountered in this research and perceived child and teacher well-being may counter such criticisms.

Despite possible links between values and well-being, evidence collected during 40 teacher development sessions in the UK indicated that teachers are rarely asked to consider their personal values (Barnes, 2013). The most likely context for reflecting on values is during interviews. Approximately 2500 interviews of prospective teachers during my life as a head teacher and teacher educator, produced clear indicators of the values they claim. Most maintain to be guided by beliefs in fairness, happiness, communication, compassion and hopes for a better world. Doubtless some were driven by expectations of 'political correctness' but few teachers choose education for the pay, or out of beliefs in discrimination, segregation, paperwork or specific teaching methods. 
The values identified at teacher interviews however, seem sadly absent from many structures and policies guiding education. In current recommendations governing English Initial Teacher Education (ITE) - even the word 'values' is absent (Department for Education (DfE), 2018). The statutory 'Standards' for ITE highlight 'British' values'(DfE, 2013), but exclude more widely understood values like hope, kindness, trust or fairness. ITE and Continuing Professional Development (CPD) strategies focus on implied values like separation, competition and compliance (see Alexander, 2010). This mismatch between initial motivations for teaching and the realities of training and teaching life is concerning. Exit interviews with those leaving teaching early, frequently raise values-conflicts that merit urgent attention from education decision-makers.

Disappointment drives many from teaching. British and American teachers commonly blame excessive workload, disproportionate accountability measures, poor pay, lack of professional and public support, bad leadership, challenging pupil behaviour and diminished creative opportunities for their decisions to leave (Guardian, 2016; National Education Union 2016; National Union of Teachers, 2018; Cooper Gibson Research/DfE, 2018; ATL, 2015; Washington Post, 2017; Why Teach? 2018) - and increasing numbers are leaving (House of Commons (HoC), 2019; Learning Policy Institute 2017; Wall Street Journal, 2018). In England fewer than 50\% of teachers have taught for more than 10 years, $10 \%$ leave each year and almost 30\% depart within five years of qualifying (HoC, 2019). Targets to fill vacant secondary teaching posts have been significantly missed in almost every subject since 2014 (Schools week, 2017) and applications for Post Graduate Certificates (PGCE) are down 33\% (SecEd, 2017). Poor US and UK training and employment figures together with reports of serious declines in teachers' mental health (Education Support Partnership, 2018; We are Teachers, 2018) have resulted in widespread perceptions of crisis in teaching, (TES 2017; Guardian 2018; HoC, 2019; Time Magazine 2018).

Education policymakers offer few fundamental solutions. 'Four Day weeks' (Guardian, 2019), bursaries and minor adjustments to curriculum are suggested, but inaction characterises many official responses to the crisis. 'Regional and institutional variations' are used to justify inertia in the UK, but even government briefings highlight the DfE's 'weak understanding of regional and local teacher supply issues' (HoC, 2019, p.51) and conclude government has '...given insufficient priority to teacher retention and development.' (HoC, 2018, p 38)

Teachers that stay in education point towards a solution. They cite friendship, recognition/appreciation from management, witnessing/facilitating the holistic development of children and opportunities for creativity as keeping them fulfilled and resilient (Booth, 2012; Kell, 2018). Such evidence suggests that paying greater attention to teachers' initial, inclusive, values and ideals might help address the retention crisis.

\section{This Study}

Funded by a UK National Teaching Fellowship award, my research focused on 5 non-western schools in which I wanted to ask about values. 43 years of teaching in the UK and the 'developing world' suggested to me that similar values unite effective colleagues, regardless of country or culture. Towards the end of a life in education I wanted to examine the validity of this impression by asking international colleagues 'What is the role of values in recruiting, retaining, sustaining and building the creative capacity of teachers?'

Earlier study in the UK established Interdisciplinary praxis-focused auto-ethnography (IPFA) as an appropriate framework for this task (Barnes, 2014). Combining approaches from sociology, philosophy, psychology and education studies, IPFA interprets auto/biographical values-discussions and stories. It aims to influence professional practice positively. Applying this interpretative framework I found values, creativity and friendships were primary sources of fulfillment and resilience in many teachers (Barnes, 2013). By extending my existing research to include long-serving colleagues in Asia and Africa I sought to examine the role of values in retaining and developing teachers by asking the following sub-questions:

a) What are your key values?

b) When were you first aware of of these values?

c) Who/what helped you form them?

d) What helps sustain them?

e) What pressures threaten your values?

Semi-structured, extended dialogues on values were held with a sample of 16 long-serving elementary teachers in five schools. The schools were chosen because of their high-profile focus on values and through direct personal and professional contact in my work as a teacher educator. In Rwanda (17.09.2016 - 29.09.2016), I visited the Rise to Shine (RTS) Primary School, outside Kigali. This school had been recommended by an ex-refugee and colleague and was founded by a non-teaching couple of Tutsi heritage in a locality where the majority population are of the Hutu cultural 
group. Founders and teachers have dedicated their lives to repairing the dreadful effects of genocide through building peaceful, trusting, cooperation and friendship between formally warring groups. In Tamil Nadu, south India I worked with two schools known to me through ITE study tours, Ghandiji Middle School in Dindigal (GMS) and the Awake Mercy Home, Primary School (AMH), (20.11.2017 - 09.12.2017). GMS serves 200 children in a poor area of town. AMH cares for 50 destitute and orphaned children in the countryside beyond it. Both schools follow the Ghandian philosophy of religious equality and pacifism. Children and staff live, worship and learn together, specifically aiming at building a harmonious, hardworking community and society. The Japanese Soka Elementary school (30.04.2018 14.05.2018) was highlighted in my doctoral studies (Barnes, 2012) on values and is located in the city of Osaka has 500 pupils. It serves a mainly professional and semi-professional community. It was founded by philosopher and disarmament champion Daisaku Ikeda and partly funded and administered by a secular Buddhist organisation called Soka Gakkai, (SG) meaning 'values creation'. The school avoids contact with temples and religious officials, but follows Buddhist principles of non-violence and world peace in it's curriculum and relationships. In February 2019 I interviewed teachers in the Awra Amba (AA) community while visiting other projects in Ethiopia.

Standard interactions were applied in each school:

- A tour

- Observation of a range of lessons

- Teaching a class of 8/9 year olds, myself

- Informal semi-structured values-conversations with volunteer teachers

- The completion of a 'values hand' by the volunteer teacher

- Staff development meeting with all staff on values and the curriculum

- Feedback to schools on observations.

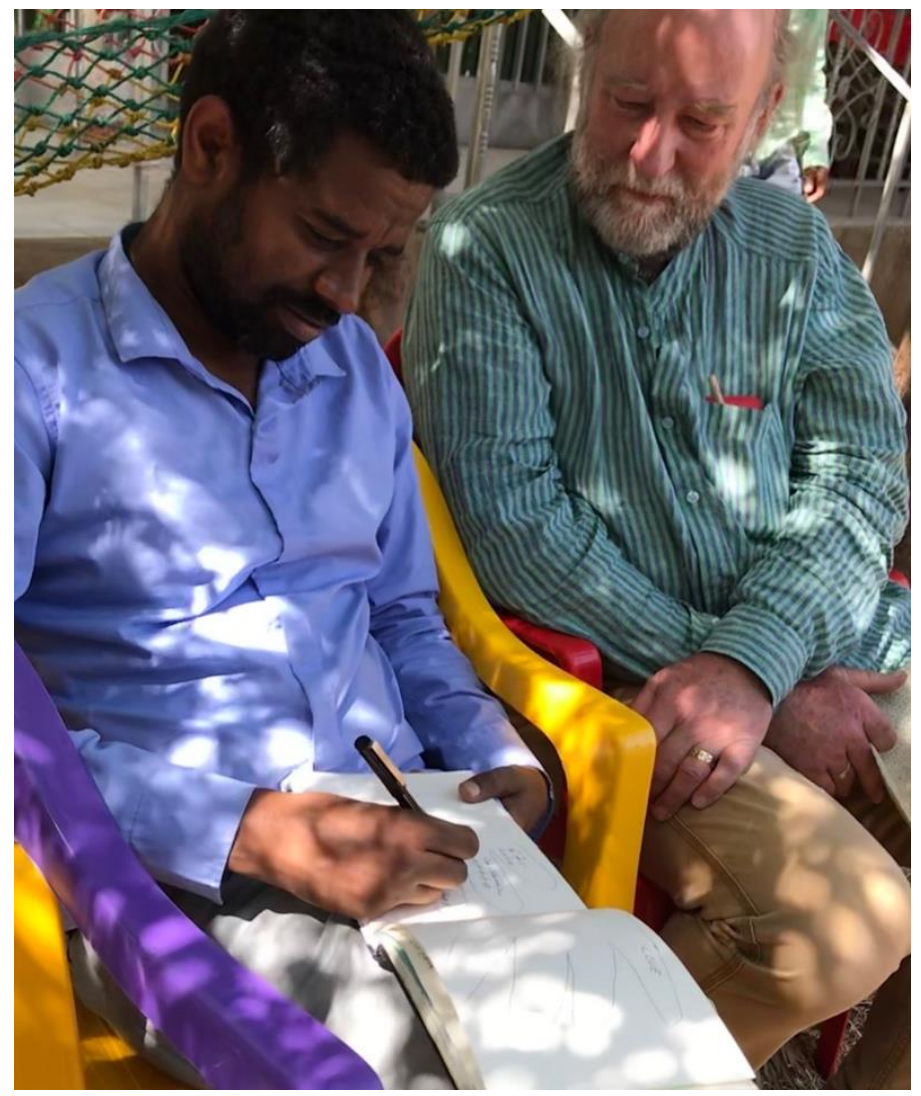

Illustration 1. Completing a values hand in AA Ethiopia

Notes were taken during each interaction and a translator/secretary captured conversations in writing and photographs. School managers attended some meetings. Written notes were scoured for themes, categories and properties in the manner of grounded research (Glaser and Strauss, 1967).

Teachers were prepared by a letter that included a definition of values and the discussion questions. The theme of values 
was initiated practically by completing a 'values hand' (see illustrations 1 and 2). Subjects drew around their hand and wrote four or five values that were most important to them in its fingers. The annotated hand drawings quickly made discussions personal and practical, limited the number of values and scaffolded conversation.

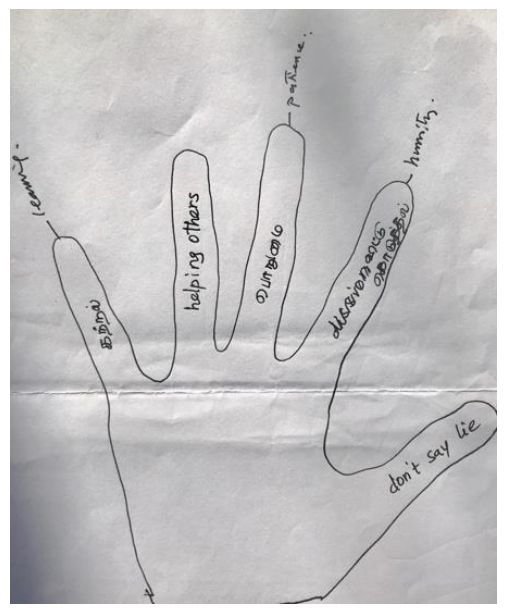

Illustration 2. A Values hand from GMS, Dindigul, Tamil Nadu

ITE institutions were also visited in each country. Discussions were held with staff at Madurai University's Department of Religion and Philosophy and ITE tutors at Lakshmi Vidya Sangham Teacher Training Academy. Staff at Soka University Tokyo, were interviewed and in Rwanda I met with senior Board of Education representatives.

\section{Ethics}

Conversation partners were volunteers with 10-30 years' teaching service. All had been informed of conversation themes and guaranteed anonymity, the right not to answer questions and opportunities to read records of their conversations. The 2-hour conversations took place in environments favorable to informal, friendly interaction. Permission was asked to share anonymous values-stories between teachers involved in the study. Schools were promised copies of the report before publication and invited to comment, change or redact items pertaining to the conversations. Though some answers may have been influenced by expectations of the values a westerner might expect, this tendency was moderated by the following features:

- Each teacher was observed teaching. Approaches were discussed with them and colleagues.

- An independent indigenous translator was included in conversations and acted as a cultural interface.

- The background and claimed values of each school was researched through desk studies.

- Time was allocated for 'off the record' conversation with participants away from school.

- Members of the local community were asked to characterise the school.

- Comparative visits were made to schools not involved in the research.

\section{Findings}

Notes, recordings and written records were analysed using the IPFE framework and Grounded Research techniques. They are summarised below under headings from the sub-questions.

\subsection{What Are Your Key Values?}

Each teacher quickly and confidently identified their personal values, linking them thoughtfully to their teaching. This clarity was perhaps unsurprising - they knew what I would ask and worked in schools where values were often discussed and habitually acted upon.

Strong themes emerged from analysis. The values recorded in Table 1 (below) were cited by four or more teachers across the settings. Value-words used several times by the same teacher were counted only once: 
Table 1. Value-words used by teachers describing their approach to education

\begin{tabular}{|c|c|c|c|}
\hline $\begin{array}{l}\text { Value-words arising from conversations with long serving } \\
\text { teachers }\end{array}$ & $\begin{array}{l}\text { Frequency of } \\
\text { references }\end{array}$ & & $\begin{array}{l}\text { Frequency of } \\
\text { references }\end{array}$ \\
\hline $\begin{array}{l}\text { Love/caring/compassion/kindness/ } \\
\text { helping others/service/alleviate poverty }\end{array}$ & $16 / 16^{1}$ & $\begin{array}{l}\text { Listening to } \\
\text { others/communication }\end{array}$ & $7 / 16$ \\
\hline $\begin{array}{l}\text { Human dignity/pacifism/ } \\
\text { peace/hope/sanctity of life/'refraining from terrifying deeds' }\end{array}$ & $15 / 16$ & $\begin{array}{l}\text { Tenacity/perseverance } \\
\text { 'unfased in the face of trouble' }\end{array}$ & $6 / 16$ \\
\hline $\begin{array}{l}\text { Community/collective } \\
\text { responsibility/justice/fairness/equality/respect/cooperation/servi } \\
\text { ce }\end{array}$ & $15 / 16$ & Faith (religious) & $4 / 16$ \\
\hline $\begin{array}{l}\text { Trust/integrity/openness/honesty/ } \\
\text { Truthfulness/trustworthiness }\end{array}$ & $10 / 16$ & Forgiveness & $4 / 16$ \\
\hline Positivity/encouragement/self-confidence/happiness & $10 / 16$ & Patience & $4 / 16$ \\
\hline $\begin{array}{l}\text { Humility/selflessness/avoiding 'vain } \\
\text { gratitude/obedience }\end{array}$ & $10 / 16$ & Creativity & $4 / 16$ \\
\hline Discipline/self-control/'rules following' & $9 / 16$ & $\begin{array}{l}\text { Science } \\
\text { Learning/learning/knowledge/e } \\
\text { ducation }\end{array}$ & $4 / 16$ \\
\hline Reliability/constancy/accountability courage/responsibility & $10 / 16$ & Friendship & $4 / 16$ \\
\hline
\end{tabular}

The values-groupings in Table 1 are tentative. Booth's (2012) 'Inclusive Values' framework suggests categories of structure, relationship and spirit, that distinguish values by their properties evident in daily life. The term 'inclusive values' will be used to indicate altruistic responses that appear commonly understood across many cultures. Re-distributing 95 recurring values-words within Booth's frame revealed commonalities ${ }^{2}$ across schools (Table 2)..

Table 2. Values of structure, relationship and Spirit (Booth, 2012)

\begin{tabular}{|c|c|c|c|c|c|}
\hline & $\begin{array}{l}\text { Ghandiji Middle } \\
\text { school }\end{array}$ & $\begin{array}{l}\text { Awake Mercy } \\
\text { School }\end{array}$ & $\begin{array}{l}\text { Soka Elementary } \\
\text { School }\end{array}$ & $\begin{array}{l}\text { Rise to Shine } \\
\text { school }\end{array}$ & Awra Amba \\
\hline $\begin{array}{l}\text { Values } \\
\text { structure }\end{array}$ & $\begin{array}{l}\text { Equality } \\
\text { Fairness } \\
\text { Justice } \\
\text { Social } \\
\text { responsibility }\end{array}$ & $\begin{array}{l}\text { Learning } \\
\text { Learning } \\
\text { Community } \\
\text { 'rules following', } \\
\text { Punctual }\end{array}$ & $\begin{array}{l}\text { Learning/education } \\
\text { Community } \\
\text { Discipline } \\
\text { Human revolution } \\
\text { Seeking growth and } \\
\text { development of children* } \\
\text { Collective-responsibility }\end{array}$ & $\begin{array}{l}\text { Justice* } \\
\text { Democracy* } \\
\text { Community }\end{array}$ & $\begin{array}{l}\text { Equality } \\
\text { Education } \\
\text { Alleviate } \\
\text { poverty } \\
\text { Democracy } \\
\text { Community }\end{array}$ \\
\hline $\begin{array}{l}\text { Values } \\
\text { relationship }\end{array}$ & $\begin{array}{l}\text { Trust } \\
\text { Compassion } \\
\text { Friendship } \\
\text { Sanctity of life } \\
\text { Forgiveness } \\
\text { Respect } \\
\text { Love kindness } \\
\text { Care } \\
\text { Acceptance }\end{array}$ & $\begin{array}{l}\text { Responsibility } \\
\text { Obedience } \\
\text { Helping others } \\
\text { service } \\
\text { service } \\
\text { Honesty } \\
\text { Honesty } \\
\text { Non-violence } \\
\text { Communication } \\
\text { Love } \\
\text { Love }\end{array}$ & $\begin{array}{l}\text { Pacifism } \\
\text { Pacifism } \\
\text { Equality } \\
\text { Neutrality } \\
\text { Wisdom } \\
\text { Gentleness }\end{array}$ & $\begin{array}{l}\text { Communication } \\
\text { Communication } \\
\text { Forgiveness } \\
\text { Obedience } \\
\text { Trust } \\
\text { Service } \\
\text { Cooperation } \\
\text { Love }\end{array}$ & $\begin{array}{l}\text { Respect } \\
\text { Help } \\
\text { Service } \\
\text { Care } \\
\text { Peacefulness } \\
\text { Love }\end{array}$ \\
\hline $\begin{array}{ll}\text { Values } & \text { of } \\
\text { Spirit. } & \end{array}$ & $\begin{array}{l}\text { Integrity } \\
\text { Courage } \\
\text { Creativity } \\
\text { Patience } \\
\text { Religion }\end{array}$ & $\begin{array}{l}\text { Patience } \\
\text { Humility } \\
\text { Happiness } \\
\text { happiness } \\
\text { Joy } \\
\text { Faith } \\
\text { Optimism } \\
\text { Tenacity } \\
\text { Selflessness } \\
\text { Avoiding vanity }\end{array}$ & $\begin{array}{l}\text { Faith } \\
\text { Hope } \\
\text { Happiness } \\
\text { Happiness } \\
\text { Happiness } \\
\text { Peace } \\
\text { Gratitude* } \\
\text { Humility } \\
\text { Encouragement } \\
\text { perseverance Selflessness } \\
\text { Selflessness } \\
\text { Joy }\end{array}$ & $\begin{array}{l}\text { Tenacity } \\
\text { Forgiveness } \\
\text { Faith } \\
\text { Keep trying } \\
\text { high ambitions* }\end{array}$ & $\begin{array}{l}\text { Kindness } \\
\text { Consideration } \\
\text { Sacrifice* } \\
\text { 'peace for the } \\
\text { globe'* } \\
\text { humility } \\
\text { others first } \\
\text { hard work* } \\
\text { faith }\end{array}$ \\
\hline
\end{tabular}

Values of Spirit and Relationship outnumbered those of Structure. Practical approaches relating to such values were readily observable in interactions in class, discoverable in quotations and descriptions, and confirmed by colleagues,

\footnotetext{
${ }^{1}$ fractions of 16 (e.g.14/16) indicate the number of teachers representing a particular activity, value or category of values.

${ }^{2}$ values common across all schools represented in this research are emboldened.

${ }^{3}$ values words marked $*$ are absent from Table 1 because claimed by fewer than four teachers.
} 
managers and founders. National or cultural characteristics emerged in choices of value-words, however. 'Discipline', 'selflessness' and 'collective responsibility' were commonly referred to in Japan and Ethiopia; communication and perseverance more popular choices in India and Rwanda. 'Happiness' was a popular choice in Japan and India but not in Rwanda or Ethiopia. When categories and properties from values-conversations were shared with colleagues in other countries however, they were quickly understood, appreciated and enthusiatically discussed.

Unexpectedly, the collected values largely avoided the essentialist, instrumentalist, target/standards-driven philosophies dominant in national education policies and debates. Teachers predominantly claimed values aligned to vocational, social reconstructionist, liberal or humanist philosophies. Exceptions: 'rules following', punctuality, neutrality, high ambitions and obedience, were few (2/15) and consistently identified alongside social values like honesty, service and humility.

Text $\cdot$ from 'values 'hand, 'Ghandiji $\cdot$ Middle $\cdot$ School, $\cdot$ INDIA

Teacher·JP

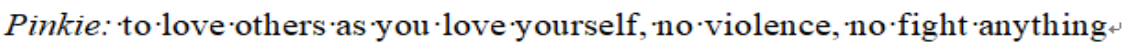

Ring finger $:$ live 'in happiness 'every 'moment, $\cdot$ learning $\cdot$ from $\cdot$ children

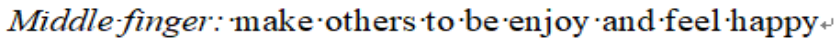

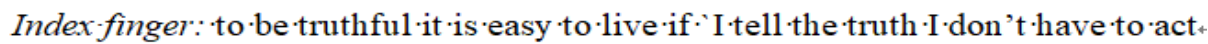

Thumb: 'Equality to 'have'good'faith that all are the 'same

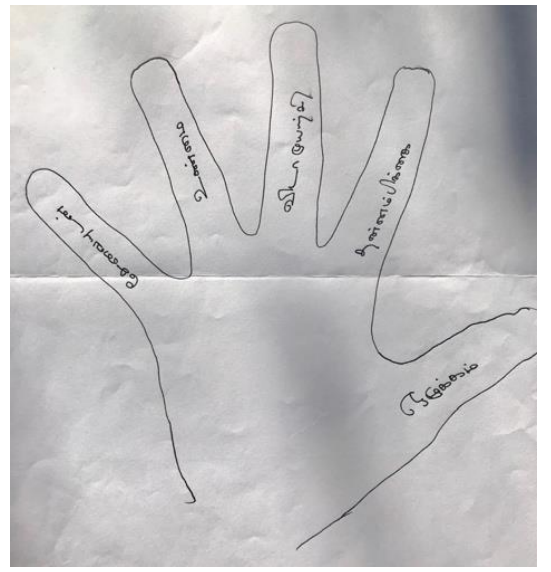

Illustration 3.A values hand from the Awake Mercy Home, Tamil Nadu

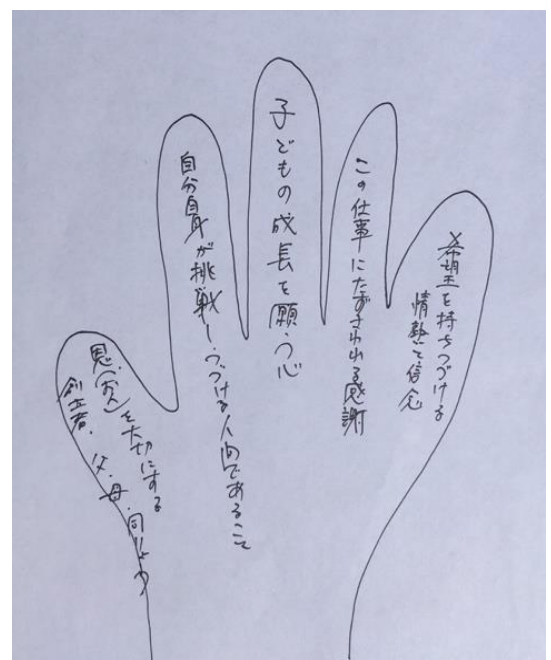

Illustration 4. Values hand from Soka Elementary School, JAPAN 
Translated 'text $\cdot$ from 'values-hands ' at $\cdot$ Soka $\cdot$ Elementary $\cdot$ School, $\cdot$ Osaka

Teacher $\cdot \mathrm{M}$

Thumb: 'Treasure 'my 'debt 'of 'gratitude to 'my f founder, father $\&$ mother, 'colleagues.

Forefinger: $\mathrm{Be} \cdot \mathrm{a}$ person who continues to 'challenge myself.

Middle finger: Have the heart that 'wishes for children's 'growth.

'Medicinal' finger: Have appreciation to 'be a a part 'of this 'job.

Pinkie: Passion and faith to have hope.

Teacher $\cdot \mathrm{B}$

Thumb: For the realization 'of children's happiness and happiness ' of each ' individual.

Forefinger: For 'my 'own 'human 'revolution (growth).

Middle finger: For the realization ' of 'world peace/kosen-rufu 'and to 'widely 'declare it .

'Medicinal' finger: For the growth 'of 'young · teachers and development ' of the educational'community.

Pinkie: A'society positive about education.

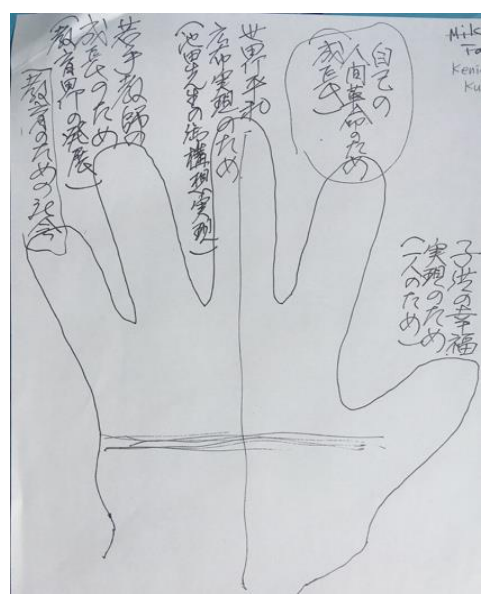

Illustration 5. A second values hand from Japan showing an intersection of core values

\subsection{When Were You First Aware of Your Chosen Values?}

Common facial and bodily manifestations of sustained thought and accompanied this question (see Ekman, 1989; 2004). Chins were cupped, looks strayed upward, eyes unfocussed and brows furrowed regardless of culture. In this common posture most teachers (12/16) related their values to events or people from childhood. For example:-

'....always, even as a young child I felt a great compassion for those in need around me. When I was about 6 or 7 I used to visit my bother who was sick in hospital. We would take him food and I saw there were others who had no food so I would take food to the other kids who were sick, I did it many times...I think I wanted to be like the Sisters of Mercy who lived nearby, I remember I really envied them - I remember saying to my mother, “Do you know what I'm going to do, I'm going to work with Mother Theresa...” B. Rwanda

'...I still treasure my experience at school with one teacher Mrs Yakiama in grade 3 [7 year olds]. Her attitude become the basis of my own values. She praised kids and taught well, we loved her. She let me me create my own play ... This play gave me confidence, I told myself "I can do this," - I have never forgotten it. 'M. Japan.

'...from a child I wanted to live in a place where women and men live as equals and where all of our children can go to school. I didn't want religion and tradition to dictate every aspect of our lives... ', Z. Ethiopia

Stories coloured every values-conversation. Folk tales illustrating humility or trust, stories of 'playing schools' or incidents that clarified the birth of a value were used by all teachers.

Japanese teachers (4/5) chose their Junior High School years (13 - 15 years) as the dawn of values-awakening. Indian teachers commonly identified Lower Primary school (6 -10 years). Among the Rwandan and Ethiopian teachers only one story involved a family event in childhood, while four told of influential, compassionate, generous teachers. 


\subsection{Who/What Helped You Form Your Values?}

Past teachers were significant sources of personal values. Their names, sometimes from over 30 years before, were rapidly remembered. F from Rwanda described teacher Daniel, '... sooo lively and who moved all around the classroom and used great songs to interact with us, he cared so much for us...'. F then sang the French song Daniel taught him, with great emotion and tears in his eyes. IS spoke enthusiastically of a teacher's 'trust and compassion,' adding:

'...if I was away for a day he would even visit my home to make sure I was OK... My cousin was often unable to pay school fees and would be sent back home, but he would say .... "take the money out of my salary this month to pay the fees". He ensured that I take part in all school activities, my leadership traits were spotted by him, He exposed me to challenges and opportunities... his personality contributes to my actions today.'

SG president Ikeda and Z the founder of Awra Amba were credited as the inspiration of values. Teachers described emotional, warm, gentle and direct interactions with these mentors early in life. Their philosophy was read and discussed at home, but teachers were keen to stress their views were personal, secular, not religious, for example:

My beliefs are my own original ideas helped by Ikeda and I have tried to follow his philosophy, to open children's creative lives by human revolution, to open our Buddha-hood and become Buddhas so that we can effect change in others. This brings a feeling of joy in my life as I see each child developing its own creative life and unlimited potential....." $\mathrm{KK}$, Osaka

Family inspired values too. SO from Osaka, told how his mother raised him, '...In the principal of serving others and making them happy,' and how he sought a job, '...that fitted that principle.'. MT from Tamil Nadu described parents demonstrating values:

'... because of my father only, I am sitting here, our family background is so different from these students, they are really poor children, when they come to school they are already hungry, they don't have enough clothes and they have such a different attitude, but my father pleaded with me to accept their family backgrounds, and teach them not to use bad words and lead them to better satisfaction with life - he told me so many moral stories from the Ramayana to support this'.

Curriculum subjects encapsulated fundamental beliefs for two teachers. One traced the emergence of passions for science, mathematics and history to his solitary childhood following his station-master father to many outlying places:

I became curious about different things. Living by the ocean I liked collecting stuff, flowers, fossils and rocks in the mountains...in another place I remember wondering at the remains of ancient arches ... 'SO Osaka.

Negative experiences were influential too. Two told of mothers humbly responding to violent or drunken partners, others related specific kindnesses during difficult periods of life. Z's parents and later his wife disowned him for his championing of equality and peace, Another confessed:

I was a most difficult child...I left kindergarten at 3 years and hardly went back to school until I was eight, I hated school. I didn't meet any good teachers that understood me and therefore I wanted to be a better one...I couldn't trust my teachers, I felt alone...only my mother stood by me and accepted me and never said I was no good, she continued to believe in me no matter how many times I betrayed her...she just prayed a lot and waited (SK Osaka).

SK remarked that this experience engendered beliefs in patience and understanding. 'People can change - everyone has, enormous potential, ' she said as she penned a Japanese character uniting the concepts of 'education and faith'.

Another 'school refuser' described his teacher's sensitivity to individual needs. He reported her gentle admonition, '...if you go on behaving in this way you will gain very little," and told how kindly support,'...with just two or three questions, highlighted her expectations...'(M, Osaka). He re-entered school and passed his exams.

M shares this story when supporting children with difficulties and ended our discussion with the following statement:

'... I want to contribute to society, humanity and the happiness of others, it's a vow that I want to hold for the rest of my life. The constant question in my mind is: "To what purpose are you doing this?" the answer is that I am here to help these students grow and positively change their perspective whether they like me or hate me.'

\subsection{What Helps Sustain Your Values?}

Prayer was an unexpectedly regular theme in conversations. Most teachers (12/16) directly raised its importance in sustaining values. Every AMH school day started with children's extemporary prayer addressing the day's needs (sick animals, poorly children, repairs, uniform, school bags, transport) and gratitude for gifts (food donated, their rabbit's safe delivery of five young, house painting finished). Prayer was interfaith, fervent and emotional. Teachers did not always know what faith the children belonged to. Days ended with house parents, visitors, teachers and students 
cross-legged in a white-painted, religious-image-filled 'meditation room' where silence and formal prayers initiated by children from Hindu, Muslim and Christian traditions were accompanied by the passing of burning oil lamps.

SG teachers referred to 'daily prayer and meditation, 'despite eschewing temples and priests. SK remarked that:

'... imparting knowledge is less important than understanding, we must try to impart wisdom. We should pray for the child's happiness, then you can bring forth wisdom, through prayer you bring forth wisdom.'

The Rwandan day began with Christian prayer, informal for teachers and formal for children, both shared properties of deep involvement.

Values-sustenance was also traced to written sources. "Stories of the great religions support our current values... without religion how do we find our values?" asked one Indian lecturer. Biblical quotations, Ghandi's writings, the Koran and Ramayana all provided reinforcement to moral thought and action. The Buddhist 'Lotus Sutra' was cited by three SG teachers. A mantra from it recited daily in private meditation and describes the path to enlightenment, thus:

'those that ...preserve pure conduct and dwell together with gentle people, who are patient and have no anger are firm in their intentions and always hold meditation in high regard, who attain profound samaddhi, [a state of meditative consciousness] and make vigorous efforts, persevere in all good practices, whose wisdom is keen and who answer difficult questions skillfully.... such people ... are near to highest, complete enlightenment, and are seated under the bodhi tree [the tree where the Buddha gained illumination], (Kobo and Yuyama, 2007, p241).

Several teachers (4/16) reported values-sustaining friendships. Indian colleagues enthusiastically celebrated religious holidays with friends of other faiths. An ITE provider claimed that attending joint ceremonies, dances, meals and processions, brought:

'...peace and tolerance, love, mutuality, unity, diversity and tolerance, grace, love and a sense that "we worship the god in you," when we collaborate together. TK, Tamil Nadu

Friendship was considered essential to holistic education. Regular assessments measured ITE students' ability to, '...form supportive relationships and work, ... in productive, creative teams' and recognized that such relationships supported,'... the mental well-being of teachers'. Compassion, confidence, sharing and 'healthy competition' - were integrated into all subject teaching and expected in students' lesson plans.

Curriculum and pedagogy can also sustain values. A Rwandan teacher used role-play in English teaching and reflected on the ways this confirmed his cherished values of relationship and spirit, commenting: 'It boosts creativity, communication, assertiveness, expression, cooperation ..., all skills that needed developing during the learning process. (BR Rwanda)

Rwanda's primary curriculum explicitly aims to build and sustain values. It highlights those necessary to rebuild a traumatised country. Its 'Social and Religious Studies' curriculum for 9 - 11 year olds for instance covers: Environmental conservation, Financial education, Gender issues, HIV/AIDS, Nutrition, Peace education, Genocide and Inclusive education...' (Rwanda Education Board (REB) 2015). Children it says, should be:

'...liberated from all kinds of discrimination, including gender based discrimination, exclusion and favouritism, ...to contribute to the promotion of a culture of peace and emphasize Rwandan and universal values of justice, peace, tolerance, respect for human rights, gender equality, solidarity and democracy'. (REB, 2015, p. 8).

Tamil Nadu's curriculum also introduces values. 8 year olds for example should learn that, '...our wellbeing is connected to the well-being of others'; 9 and 10 year olds should understand that, '...different people in India are expected to live together and respect each other', ' and 11 year olds must study, 'prejudice, discrimination, inequality and 'understanding diversity'. (Tamil Nadu Board of Education, 2017)

\subsection{What Pressures Threaten Your Values?}

Maintaining inclusive values is difficult. Lives are messy; principles constantly threatened. Each teacher told of values-challenges and compromises but claimed schools and colleagues helped them stay faithful to their guiding principles. The evidence indicated that inclusive values at the heart of curriculum, pedagogy, relationships and environment gave teachers high degrees of values-resilience. These values had become essential to their schools' ethos and well-evidenced success - 'Ghandian', in south India, 'secular Buddhist' in Japan, 'equality' in Ethiopia and 'trust, love and togetherness', in Rwanda (Wellspring foundation, 2018). Teachers were appointed for such values and retained if they continued to build on them. While in Rwanda an academically and professionally able teacher was dismissed with the words, 'you failed to live the trust and love expected by the school'.

Many teachers used the pronouns 'we', 'us' or 'our" when describing school life, for example:

'we work together, meditate together and share everything with the children...day by day we are updating 
ourselves, using many incidents from the daily life of our children in our teaching.' SV Tamil Nadu.

Discussants did not disguise their difficulties however. Several confessed to values-conflict, struggles in sustaining hope or positivity. For example, while writing, 'to live happy in every moment, ' in his values hand, one teacher shared his distress at the suicide of a close friend 10 years earlier and said:

I now want to live...just like the children ... closely observing the life of the founder and his wife whose kindness and non-violence show us the best of what is human.' (JP. Tamil Nadu).

\section{Discussion: Learning From the Experience of Teachers Outside 'The West'?}

Each school in this study aims at values-creation. The high profile of values may seem exotic but it is proposed the schools offer models transferrable to foundering education systems in the west. Chosen for their un-representative qualities the subject schools demonstrated through their established teachers, the potential positive impacts of values-centric approaches. Lesson observations, discussion, peer appraisals and reputation provided multiple examples of teacher resilience, energy, positivity and creativity that arose from consistent values.

Teacher resilience matters - it has a profound influence upon children's learning. Though teachers in this study acknowledged discipline, pay, workload and management issues, the primacy of inclusive values appeared to hold them to affirmative attitudes. The evidence continually suggested that the close alignment of personal and institutional values generated positivity, inner strength and creativity in each individual teacher. This apparent well-being gave rise to lively, egalitarian practice. The validity of such claims must however be tested in wider research.

Caring professions like teaching tend to attract people who prize meaning-making and human interaction. Daily contact with ordinary people helps them appreciate the significance of communication and positive emotions ${ }^{4}$ for a life with well-being. Effective teachers understand how making personal, emotional and valuable connections sustain learner motivation and provide meaning and creative direction to learning (Csikszentmihalyi, 1997; Perkins, 2014; Robinson and Aronica, 2015). As global threats increase and change accelerates, recruiting and retaining excellent teachers equipped to make the world a better place may be crucial to human survival. This study has raised questions relevant to this assertion:

1. What is the potential role of values in teachers' professional lives?

2. Are there cultural differences in teachers' values?

3. Is there any universality in the values expressed by teachers?

4. Are values connected with individual and community well-being?

\subsection{What Is the Potential Role of Values in Teachers' Professional Lives?}

The sample teachers asserted that living certain values improved the quality of children's' learning and lives. The emergent themes of stories, service, faith ${ }^{5}$ and prayer/meditation ${ }^{6}$, reminded that such values arise from bigger structures like religion, family and culture but also from chance encounters. I have claimed that inclusive values are closely linked to effective teaching and learning. The evidence of this study indicated that when teachers were able to live the values with which they entered education, their children developed mindsets (Dweck, 2017) conducive to learning. They:

1. Developed confidence.

2. Experienced positive emotions.

3. Showed more kindness.

4. Were conscious of common humanity.

5. Demonstrated commitment to community.

\subsubsection{Confidence}

Many values cited are associated with confidence. A sense of community, compassion, respect, trust, fairness and positivity are part of what Bandura (1997) calls self-efficacy. My previous, extended personal experience in African and Asian primary schools suggested that children in the study schools displayed uncommon degrees of self-assurance and

\footnotetext{
${ }^{4}$ see Damasio, A. (2000) for distinctions between emotions and feelings and Fredrickson (2009) for expansion on the significance of positive affect.

${ }^{5}$ Faith: the belief in a higher cause or meaning.

${ }^{6}$ Prayer/meditation: an ecstatic focus on gratitude, humility and hope in the context of that higher cause or meaning.
} 
this may have been one result of the unusually consistent positive relationships between them and their teachers.

Western perspectives see confidence as a prerequisite for effective learning and successful social functioning (Bandura, et al. 2003; Dweck, 2017). Outside the west, individualised confidence is not so admired (Cave, 2001). The degree to which personal confidence serves community, conformity and cooperation is more important. Binary distinctions between individual and community confidence may be unnecessary however. In Japan for example teachers looked, 'within themselves' to address the challenges offered by individual children. Prayer and meditation was directed towards their and pupils' 'personal transformation' (MT) and they used each curriculum subject to signpost the journey from 'ignorance, selfishness and violence, towards wisdom, peace and compassion' (SK). Negative dispositions were always 'open to positive change' (MM) and confidence was expected to grow in communal rather than individual contexts. Confidence was claimed by 9/16 teachers to generate creativity in themselves and their students.

In AMH and GMS confidence stemmed from Gandhi's pacifistic, disciplined and respectful philosophies. Rwandan teachers spoke of, '... all being God's children,' when describing the role of Social Studies teaching in confronting ethnic hatred. In the words of one:

'I always wish the best for my children, scripture (Proverbs, 22:29) mentions that the skilled will serve kings ... based on this I try my best to ensure that necessary skills and values are passed to my children to enable them to become successful in future and serve and be served as kings.'(IS, Rwanda)

\subsubsection{Positivity}

Teachers' references to values of spirit were particularly common. Their key-stories demonstrated beliefs that these positive values were not necessarily inborn. About half (7/16) shared details of unhappy, dislocated childhoods, poverty, violence and discrimination - experiences that might easily have triggered negative life-trajectories. Optimistic and constructive attitudes appeared to have emerged from frequent and structured opportunities to build stories from values admired in childhood. While sharing their values-stories the demeanor of literally every teacher changed, approaching Fredrickson's (2009) description of a whole system in a productive and pleasant state of: '...positive meanings and optimistic attitudes ... open minds, tender hearts, relaxed limbs and the soft faces they usher in.' (2009, p.6).

Teachers avoided Pollyanna-like ${ }^{7}$ blindness to the negative, however. Rwandan, Ethiopian and Indian teachers could hardly disregard the poverty, fear and sadness around them. Their schools depended upon food and material donations from their communities and each teacher compassionately related stories about vulnerable individuals in their classes. SG schools escape the challenges of poverty but instead through curriculum and pedagogy were clearly addressing some of the negative effects of affluence. Regardless of subject or cultural context teachers shared positive, personal stories with their children that modelled values that had sustained them.

\subsubsection{Kindness}

The desire to show kindness towards children was the most common value choice of teachers. Described variously as gentleness, love, caring, compassion, empathy and service, this benevolence was evident in every face and classroom. Kindness reinforced in posters, role play, school grounds, subject illustrations and personal interactions characterised each school environment.

Beliefs in kindness did not imply license. Biblical texts quoted by Rwandan teachers described children as dependent upon being shown the 'right way'by adults. Service, sacrifice, democracy and honesty were strong expectations in AA's regular nursery children's values-meetings, but also featured in the songs they sang. Though African adults said they 'expected respect', Rwandan and Ethiopian teachers referred as much as their Japanese and Indian counterparts to learning from the children, listening and serving.

Expressions of each child's potential 'Buddha-hood' or of all being 'Children of God,' placed kindness as a response to beliefs in human inter-relatedness. As one teacher said:

.... every child has a value - their own unique potential - we have to accept that as a fact. So we have to transform ourselves to accept all of them - this is where faith and education come together for us' (SK, Osaka).

Beliefs in a shared journey towards enlightenment expressed in SG art and history sessions countered tendencies toward pride and power. Living and teaching alongside destitute children in AMH and AA engendered countless opportunities to show kindness by 'avoiding vanity', (JP) 'being humble'(SV) and 'serving others'(TK).

\footnotetext{
${ }^{7}$ Pollyanna: an excessively cheerful person, the title and subject of a popular children's book by E.H Porter (1913).
} 


\subsubsection{Common Humanity}

Conceptions of the 'oneness' of humanity lie behind the exhortations to love our neighbour and reduce inequalities which unite major religions (Alliance of Religions and Conservation (ARC), 2016) and traditional culture (Battle, 2009). The teachers in this study represented Buddhism, Hinduism, Christianity, Islam and AA's belief in an un-named creator God. All recognised the centrality of human interdependence and frailty (ARC), 2015) but this was especially evident in 2 lessons on soil conservation and food security in the AA and RTS schools where children chose vocabulary that spoke of 'sharing', 'giving', 'helping', 'harmonising with' and 'serving' others.

\subsubsection{Commitment to Community}

Accompanied by trustees, head teachers and colleagues, teachers were unlikely to criticise their institutions. Commitment to school and 'founders' was predictably expressed by all. Deeper analysis, more probing questions, lesson observations and informal interactions prompted more candid reflections. Some older teachers confessed to finding teaching increasingly demanding but reiterated admiration for those that maintained guiding principles. Loyalty to colleagues and continued dedication was evidenced in every school via free time given to school maintenance, club events and curricular expressions of communal creativity in choirs, bands and displays. Days were long and expectations higher than other local schools but comparative evidence showed significantly lower rates of teacher sickness and early retirement.

\subsection{Are There Cultural Differences in Teachers' Values?}

Every cultural context is unique. Cultures arise from different histories and fortunes. It is difficult for 'outsiders' to claim deep understanding of the words and actions of another culture. Tables 1 and 2 assume similar meanings for 'love', 'kindness' and 'equality' etc. but experience shows they rarely correlate exactly. Before discussing claims of universal human values therefore, cultural differences must be acknowledged.

Equality is not understood equally in everywhere. Whilst gender equality was claimed in Japan for instance, its language requires males and females to be addressed differently. It was hard not to interpret the dominance of male teachers and hosts in every context as illustrative of a male-dominated society, but the female volunteers contradicted this assumption. Their confidence, frankness and articulateness - often in the presence of male managers, was notable. The research conversations offered opportunities to assert an equality that may have been there anyway. The Ethiopian AA community, specifically founded upon equality between men and women, had to have the reality of that equality restated and reaffirmed in monthly meetings.

Community was another property uniting all testimonies, but experience differed. The tight and highly supportive communities served by the Tamil, Ethiopian and Rwandan schools also suffered the deprivations of poverty: ill health, few material possessions, cramped conditions, poor resources, little privacy, narrowed horizons and few links beyond the local. Community meant something wider and more technological in Japan under the influence of affluence, internet, western orchestral instruments, links with foreign schools and well-travelled teachers.

Stories are an easier context in which to discover commonalities. The mini-narratives related in every conversation succinctly expressed a range of fundamental beliefs and attitudes (see Stefanovski, 2018 below). Stories of pain or unhappiness, revelation, joy or heroism operated on planes beneath culture, touching on universal aspects of the human condition (Gottschall, 2012). Hope, compassion, kindness, service, peace-making and the sanctity of life - recurrent themes in teachers' stories - were received and appreciated across cultural divides provoking remarkably similar bodily and facial responses.

\subsection{Are Some Values Universal?}

Philosophers, psychologists, theologians and anthropologists have tirelessly attempted to establish the idea of universal values, (for example, Huxley, 1945; Tillich,1954, 1967; Brown,1991, 2000; Antweiller, 2016). In the super-diverse (Vertovec, 2007) communities of the US and UK necessarily relativistic stances to values make it possible for child 'care' to involve anything from strict discipline, indoctrination and gender separation, through to total permissiveness. Common moral understandings - perhaps the 'Golden Rule, ${ }^{8}$ (Hick, 1992) may exist, but conversations showed that love, discipline and service could be quite differently interpreted, though warmly appreciated within values-stories shared across cultures.

Today's inter-connected world also generates strong pressures towards agreement, or at least discussion, on values. This study has shown that shared understandings of key values is especially important for teachers and curriculum. Schools and ITE might begin this process by considering four values-contexts posited by Kinnier et al (2000).

\footnotetext{
${ }^{8}$ The Golden Rule: Treating others as you would wish to be treated.
} 
I. The recognition of something greater than self (e.g. faith, truth, justice).

II. Self-respect (attitudes of humility and responsibility).

III. Caring for others (recognizing human connectedness, service, non-violence and kindness).

IV. Caring for other living things and the environment.

Teachers' values reassigned in Table 3 fall easily into the first 3 of Kinnier's categories. Those concerning 'Big ideas', the 'good' self and the 'good neighbour' dominate, but as contemporary global environmental threats multiply, it is troubling that only two teachers mentioned sustainability or the natural world - Kinnier's fourth category. This suggests an urgent agenda item for ITE and ISTD everywhere.

Table 3. Common values for the teacher?

\begin{tabular}{cl}
\hline Kinnier's Universal Values & $\begin{array}{l}\text { Sample values chosen by teachers across four non-western } \\
\text { countries }\end{array}$ \\
\hline I. Something greater than self & $\begin{array}{l}\text { Faith, truth, sanctity of life, justice, community, human dignity, } \\
\text { knowledge, hope }\end{array}$ \\
II. Self respect/responsibility & $\begin{array}{l}\text { Self-control, self-confidence, happiness, discipline, obedience, } \\
\text { humility, courage, hope, reliability/accountability, constancy, patience, } \\
\text { perseverance }\end{array}$ \\
III. Respect and care for others & $\begin{array}{l}\text { Love, caring, trust, compassion, kindness, service, pacifism, equality, } \\
\text { communication, listening, forgiveness, friendship, honesty, democracy, } \\
\text { sacrifice }\end{array}$
\end{tabular}

IV. Care for other living things Spurning meat, science learning(?) curiosity and environment

Universal agreement on each value above is unlikely, but the teachers in this study consistently demonstrated properties mutually interpretable as gentle, sensitive, caring and respectful towards children. Through personal stories, they evidenced the birth, growth and curricular expression of such values. Conversations confirmed that these teachers were content to be judged by the values they articulated. Evidence of values-conflict or insincerity was absent from observations and conversations, indeed multiple examples of teachers' beliefs in ultimate meaning, self- respect and care for others were recorded in each setting. Again these 'Common values for the teacher', when illustrated in stories, appear to be viscerally understood by all who hear them.

\subsection{What Do Values Have to Do With Personal And Community Well-Being?}

Defined by Ryff, (1989) well-being combines subjective feelings of purpose, good relationships, self-acceptance, environmental mastery, positive relationships, autonomy and personal growth. Others like Czikszentmihalyi (2002) link happiness to periods of deep engagement or 'flow'. Seligman (2011) suggests well-being involves 'feeling good', accomplishment, authentic, affirmative connections and a meaningful existence. However, critics (e.g. Miller, 2008) claim such descriptions are founded on limited definitions of mental health. Scientists observing brain and body connections observe that such subjective feelings affect physical realities (Damasio, 2003, Panksepp, 2004, Gilchrist, 2010, Robertson, 2017). 'Feeling good' impacts positively upon physical functions that include digestion, blood pressure, skin conductivity, muscle tone and the immune system. The brain chemistry generated in this optimal state (Damasio, 2012) promotes tendencies towards trust, collaboration, empathy and other valued characteristics of sustainable communities. If well-being arises from our interpretations of experience, then those that teach us are crucial.

Facts can be narrated in various ways; our glass can be half-full or half-empty. Our stories define us but also those we influence. Goran Stefanowski (2018) spoke compellingly about the impact of personal narratives:

In order to survive we spin stories. For us there is nothing more important than these stories. They are the essence of our life, the backbone of our identity.

In order to survive in the cruel world, our story must be true, based on knowledge and insight. A false story could cost us dearly, lead us to delusion, a dead end, even death. Our landscapes are constantly changing, so too our stories must constantly readjust. The story is a map. If it does not correspond to the landscape, we are lost (Stefanovski, 2018, p.29-30).

My values-conversations generated abundant story maps. Neither unrealistic nor over-dramatic, these accounts had authority and authenticity. Some had been readjusted in the light of experience. One teacher spoke of entering education 
with high pacifist ideals but found the challenge of working with young people highly stressful and began to lose motivation. Supportive teacher friends helped him rediscover lost values and prompted change in his own attitude to the youngsters' behavior. 'This revolution helped me grow into values I previously understood only intellectually,' (M), who finished our conversation saying, '... teaching is now my joy'. Such 'Key-Stories' (Barnes, 2012, 2013) mark turning points in life. Their significance grows over time through reiteration and elaboration, but teachers know they can also shape children's educational experience. Observations recorded the use of fragments of autobiography in 12/14 lessons.

Autobiographical accounts frequently generate matching fragments of narrative from children (Barnes, 2018). With care, these narratives build bridges between teacher and student (Grainger et al, 2004). One Japanese teacher conscious of a cultural reluctance to speak about feelings, told of an occasion when her class's parents were asked to write a 'love letter' to their children. She related the response of a previously violent and depressed student, who:

...just became more cheerful after this letter. Within a week he nominated himself to be on the student council and shared that he'd written back to his mother three times that he was sorry to have caused so many problems. (SK)

She ended her story with, '...this reminds me why I became a teacher'.

\section{Implications for Policy and Practice in Education}

This study recorded and analyzed values-discussions with 16 well-established teachers from a range of non-western and values-led schools. It sought to discover whether aspects of their long and apparently fulfilled lives in education could offer guidance to the UK and US on how to address the current recruitment and retention crisis. The children taught by these teachers represented an economic spectrum from destitution to wealth. Schools occupied rural, semi-rural, suburban, urban and metropolitan localities. Classrooms ranged from high-tech to basic. Whatever the context, after assuring safety, shelter and sustenance, the teachers' prime focus was to enrich children's personal and community life through teaching knowledge and skills in the subjects. This study suggests that attracting and keeping teachers to fill these roles with passion and creativity, requires close attention to their values. The teachers' Key Stories, explained how their core values arose and how mental and physical well-being is enhanced by living 'in the direction' of them (McNiff and Whitehead, 2012). These values steer principled and effective approaches to subject teaching and when well cultivated add to teachers' capacity. These and other research observations suggest four major implications to be considered by governments, ITE and CPD:

Implication 1: Teachers and students should be encouraged to share their 'values-stories'

Teachers communicated their most important thoughts, attitudes and ideas through stories. These autobiographical vignettes were enthusiastically shared and built-upon in class and staffroom. They conceded that such tales affirmed them, strengthened relationships and stirred and nurtured similar values in others.

We have seen that the significance of values-stories was readily understood across cultures. An account of a child rescuing a cow in a war zone shared by a teacher from a nomadic family was instantly appreciated by the son of a Japanese stationmaster as involving values of courage and responsibility. The tale of a lost six-year-old sharing ice cream with street children under an Indian motorway was literally applauded by Rwandan teachers who knew neither motorways nor child destitution.

Teachers' stories, helped make sense of life, contributed to their resilience and according to their testimony built capacity to give and give more creatively.

\section{Implication 2: Identify and build upon values through frequent values-discussions}

Naming, nurturing and exercising teachers' virtuous values (Barnes, 2012) can bring consistency and purpose to teaching. Emphasis on values in curriculum, pedagogy and ethos appeared to motivate and offer fulfillment to the teachers in this study. Values openly expressed across school life - in planning, teaching, assessment and relationships were kept alive by frequent values-discussions.

In AA values-discussions were held monthly in every community group including the nursery school. In Rwanda animated staffroom discussion followed a class role-play exercise on kindness in the marketplace. Manifestations of generosity, the dignity of labour and non-violence arising from a GMS session on vegetarian cooking were re-visited in plenary discussions with children. In a Japanese calligraphy lesson with 458 -year-olds, the teacher highlighted community and mutual responsibility alongside instruction on brush strokes and balance.

Each school demonstrated that discussion kept values alive, reaffirmed the connecting, guiding, meaning-making aspects of education and stimulated critical thinking.

Implication 3: Build teachers' well-being by identifying, promoting and applying inclusive values at every level of decision-making 
Posters, signs and symbols around each school invited external judgment on the sincerity of their values. Physically highlighting them provided a continuous and benevolent check on adult and child action and impacted positively on teachers' well-being. Documentation expressing the aims of each school detailed their intention to build strong, caring and service-oriented cultures centred on the well-being of all. High rates of teacher retention were probably not coincidental. Many more than half the teachers in Soka schools had been there for more than 10 years, less than 2\% retire early and teachers' average age is about 40 years (SGI, private communication 04.07.18). In all settings teachers remarked positively on the close relationship between personal and school values and many illustrated strong links between their happiness and that of the children. Significantly many linked their personal happiness with increased creative practice and greater creativity from their students.

Implication 4: High quality teachers will be recruited into a profession guided by beliefs in something greater than self or culture.

Big ideas capture our attention. Views on human inter-dependence, respect for others and care for the environment, have traditionally been established and upheld by culture and religion, but in a rapidly changing, globalised, secular, unequal, damaged and technology/science-dominated world, education has been charged with leading on moral issues. These modern concerns can only be addressed by greater attention to the values by which we can live with well-being and particularly one missing from the narratives of the teachers in this study- that of environmental sustainability.

The United Nations Sustainable Development Goals (SDG) (UN, 2015) arose from recognition that to survive as a species human behavior must change. SDG on the curriculum is not enough. Societal change probably depends upon cohorts of enthusiastic, knowledgeable, confident teacher-leaders. Environmental sustainability should be a measurable outcome of values like: hope, kindness, care, perseverance, humility, community, social responsibility, service and love. The UN asks teachers to apply their values and skills to creating communities equipped to improve the environments they inhabit. The challenge of attracting and retaining such teachers was mentioned by education officials in each country represented in this research. The 16 teacher-participants offered a way forward. Through constant attention to the most virtuous of their values they had retained a vision of a better world and continue to believe that they are contributing to it. These well-tended beliefs, consolidated by unique and often shared autobiographical stories, constructed meaning in their lives and through them the lives of children. The task now is to bring the inclusive values of teachers up the agenda and so direct education towards a more sustainable future for us all.

\section{References}

Alexander, Sir R. (2010). Children, their World their Education: The Cambridge Primary Review, London: Routledge.

Alliance of Religions and Conservation (ARC) (2015) The Bristol Commitments available at: http://www.arcworld.org/projects.asp?projectID $=667$

Antweiller, C. (2016). Our Common denominator: Human universals revisited New York: Berghahn.

ARC (2016). Faith in Finance, available at: http://www.arcworld.org/downloads/Faith-in-Finance.pdf

Association of Teachers and Lecturers (ATL) (2015) Why new teachers consider leaving, available at: https://www.atl.org.uk/latest/new-teachers-already-demotivated-about-teaching-start-their-careers,

Bandura A. (1997). Self-efficacy. In V. S. Ramachaudran (Ed.), Encyclopedia of human behavior, San Diego: Academic Press.

Bandura, A., Barbaranelli, C., Caprara, G., \& Pastorelli, C. (2003) 'The role of affective self-regulatory efficacy in diverse spheres of psychological functioning', in Child Development, 74(3), 769-782.

https://doi.org/10.1111/1467-8624.00567

Barnes, J. (2012). What Sustains a Life in Education? Unpublished $\mathrm{PhD}$ thesis, Canterbury Christ Church University.

Barnes, J. (2013). What Sustains a Fulfilling Life in Education? Journal of Education and Training Studies, 1(2), 74-88. https://doi.org/10.11114/jets.v1i2.144

Barnes, J. (2014). 'Interdisciplinary Praxis-focused autoethnography, Using autobiography and the values discussion to build capacity in teachers', Advances in Social Science Research Journal, 1(5), 160-182. https://doi.org/10.14738/assrj.15.466

Barnes, J. (2018). Applying Cross-Curricular Approaches Creatively, London: Routledge. https://doi.org/10.4324/9781315513614

Battle, M (2009) Ubuntu: I in you and You in me, London: Seabury.

Booth, T. (2012). Index for Inclusion, Bristol: Centre for Studies in Inclusive Education. 
Boski, P., Strus, K., \& Tiaga, E. (2004) 'Cultural identity, existential anxiety and traditionalism,' in Bernadette, N., Setiadi, A, Supratiknya, A, Lonner, W., Ype, H. and Poortinga (2004) Ongoing Themes in Psychology and Culture, Melbourne FL: International Association for Cross-Cultural Psychology.

Brown, D. (1991). Human Universals. New York: City.

Brown, D. (2000). 'Human Universals and their Implications'. In N. Roughley (ed.), Being humans: Anthropological Universality and Particularity in Transdisciplinary Perspectives. New York: Walter de Gruyter. https://doi.org/10.1515/9783110822809.156

Cave, P. (2001). Educational Reform in Japan in the 1990s: 'Individuality' and other uncertainties, Journal of Comparative Education, 37(2), 173-191 | Published online: 28 Jun 2010.

Cooper, Gibson Research/DfE (2018). Factors Affecting Teacher Retention, available at: https://assets.publishing.service.gov.uk/government/uploads/system/uploads/attachment_data/file/686947/Factors_ affecting_teacher_retention_-_qualitative_investigation.pdf

Csikszentmihalyi, M. (1997). Creativity: Flow and the Psychology of Discovery and Invention, New York: Harper Perennial.

Csikszentmihalyi, M. (2002). Flow: The Classic Work on How to Achieve Happiness, New York: Ebury Press.

Damasio, A. (2000). The Feeling of What Happens: Body, Emotion \& the Making of Consciousness, London: Heinemann.

Damasio, A. (2003). Looking for Spinoza: Joy Sorrow and the Feeling Brain, London: Harcourt.

Damasio, A. (2012). Self Comes to Mind; Constructing the Conscious Brain, New York: Penguin Random House

Department for Education (DfE) (2013). Teachers'Standards, available at:

https://assets.publishing.service.gov.uk/government/uploads/system/uploads/attachment_data/file/665520/Teachers _Standards.pdf

DfE (2018) Statutory Guidance for Initial Teacher Training, available at: https://www.gov.uk/government/publications/initial-teacher-training-criteria/initial-teacher-training-itt-criteria-andsupporting-advice\#c21-programmes.

Diener, E., Kahneman, D., \& Helliwell, J. (2010). International Differences in Well-Being, New York: Oxford University Press. https://doi.org/10.1093/acprof:oso/9780199732739.001.0001

Dweck, C. (2017). Mindset: Changing The Way You think to Fulfil Your Potential. New York: Robinson.

Education Support Partnership (2018). Teacher Well-being Index, available at: https://www.educationsupportpartnership.org.uk/sites/default/files/resources/teacher_wellbeing_index_2018.pdf

Ekman, P. (1989). The argument and evidence about universals in facial expressions of emotion Handbook of Social Psychophysiology, eds. Wagner, H. and Manstead, A. New York: John Wiley and Sons.

Ekman, P. (2004). Emotions Revealed: Understanding Faces and Feelings, London: Phoenix.

Frankl, E. (1992). Man's Search for Meaning, London: Penguin.

Fredrickson, B. (2009). Positivity: Groundbreaking Research to Release Your Inner Optimism and Thrive, New York: Crown.

Gilchrist, I. (2010). The Master and his Emissary: The Divided Brain and the Making of the Western World, New York: Yale University Press.

Glaser, B., \& Strauss, A. (1967). The Discovery of Grounded Theory: Strategies for Qualitative Research, New York: Aldine.

Gottschall, J. (2012). The Story telling Animal, New York: Houghton Mifflin Harcourt.

Grainger, T., Scoffham, S., \& Barnes, J. (2004) A Creative Cocktail: Creative Teaching in Initial Teacher Education, Journal of Education for Teaching: International Research and Pedagogy, 30(3), $243-252$. https://doi.org/10.1080/0260747042000309475

Guardian (2019). 25 $5^{\text {th }}$ January 2019, available at: https://www.theguardian.com/education/2019/jan/25/teachers-job-share-workloads-recruitment-retention-strategydamian-hinds

Guardian, (2016). Nearly Half of England's teachers plan to leave in the next five years, available at: 
https://www.theguardian.com/education/2016/mar/22/teachers-plan-leave-five-years-survey-workload-england Guardian (2018) $1^{\text {st }}$ April 2018, available at: https://www.theguardian.com/education/2018/apr/01/vast-majority-of-teachers-considered-quitting-in-past-year-po 11

Hick, J. (1992). The Universality of the Golden Rule, in J Runzo (Ed.) Ethics, religion and the good society, New directions in a Pluralistic World, Louisville KY: Westminster.

House of Commons (2018). Briefing Paper $4^{\text {th }}$ June 2018, available at: https://dera.ioe.ac.uk/31729/1/CBP-7222.pdf

House of Commons, Briefing paper 7222, (2019). Teacher recruitment and retention in England, available at: https://www.wsj.com/articles/teachers-quit-jobs-at-highest-rate-on-record-1154599305.

Huxley, A. (1945). The Perennial Philosophy, London: Chatto and Windus.

Kell, E. (2018). How to Survive in Teaching, London: Bloomsbury.

Kinnier, R., Kernes, J., \& Dautheribes, A.(2000). A Shortlist of Universal values, in Counselling and Values, 45(1), 4-16. https://doi.org/10.1002/j.2161-007X.2000.tb00178.x

Kubo, T., \& Yuyama, A (Trans.) (2007). Lotus Sutra available at: http://www.bdk.or.jp/document/dgtl-dl/dBET_T0262_LotusSutra_2007.pdf

Lande, M. (2017). Are Teachers increasingly leaving the profession? In Professions and Professionalism, 7(2), 1-24, available at: https://journals.hioa.no/index.php/pp/article/view/1723/1775

Learning Policy Institute, (2017). Teacher Turnover: Why it Matters, available at: https://learningpolicyinstitute.org/sites/default/files/product-files/Teacher_Turnover_REPORT.pdf

Maslow, A. (1943). A Theory of Human Motivation, in Psychological Review. https://doi.org/10.1037/h0054346

McNiff, J., \& Whitehead, J. (2012). All you Need to Know about Action Research, London Sage.

Miller, A. (2008). A Critique of Positive Psychology, available at: https://onlinelibrary.wiley.com/doi/abs/10.1111/j.1467-9752.2008.00646.x

National Education Union (2016). available at: https://neu.org.uk/latest/how-bad-does-teacher-recruitment-crisis-have-be-dfe-calls-it-crisis,

National Union of Teachers (2018). Teacher Recruitment and Retention, available at: https://www.teachers.org.uk/edufacts/teacher-recruitment-and-retention

Panksepp, J. (2004). Affective Neuroscience: The Foundations of Human and Animal Emotions, Oxford: Oxford University Press.

Perkins, D. (2014). Future Wise: Educating our Children for a Changing World, San Francisco, CA: Jossey Bass.

Robertson, I. (2017). The Stress Test, London: Bloomsbury. https://doi.org/10.1016/bs.pbr.2016.12.003

Robinson, K., \& Aronica, L. (2015). Creative Schools: Revolutionising Education from the Ground Up, London: Penguin.

Rwanda Education Board (2015). Social and Religious Studies Syllabus for Upper Primary pp.4- 6, available at: http://old.reb.rw/fileadmin/competence_based_curriculum/syllabi/CURRICULUM_FRAMEWORK_FINAL_PRI NTED.compressed.pdf

Ryff, C. (1989). Happiness is everything, or is it? Explorations on the meaning of psychological well-being. Journal of Personality and Social Psychology, 57(6), 1069-1081. https://doi.org/10.1037/0022-3514.57.6.1069

Schools Week (2017). Available at: https://schoolsweek.co.uk/government-misses-teacher-training-targets-in-all-ebacc-subjects-except-history/

SecEd (2017). Available at: http://www.sec-ed.co.uk/news/gcse-entries-fall-across-all-non-ebacc-subjects/

Seligman, M. (2011). Flourish: A new Understanding of Happiness and Well-Being and How to Achieve Them, New York: Nicholas Brealey.

Stefanovski, G. (2018). The Spark which escapes - narratives between hammer and anvil, key note speech to the IFTR World Congress 2018, Belgrade, 9 July.

Tamil Nadu Board of Education (2017). Social Science Curriculum, available at: https://fullcircleeducation.in/wp-content/uploads/2017/11/Social-Science.pdf

Tillich, P. (1954). Love, Power and Justice, Oxford: Oxford University Press. 
Tillich, P. (1967). My Search for Absolutes, available at: https://web.archive.org/web/20050119030418/http://www.religion-online.org:80/showchapter.asp?title=1628\&C=1 618

Time Magazine (2018). available at: http://time.com/longform/teaching-in-america/

Times Educational Supplement (2016). available at: https://www.tes.com/news/nearly-third-new-teachers-leave-profession-within-five-years-figures-show

Times Educational Supplement (TES) (2017). Teachers mental health problems, available at: https://www.tes.com/news/teaching-driving-too-many-teachers-mental-health-problems

United Nations, (2015). Sustainable Development Goals, available at: https://sustainabledevelopment.un.org/?menu=1300

Vertovec, S. (2007). Super-diversity and its implications, Ethnic and Racial Studies, Vol. 30 No.6 pp1024-1054. https://doi.org/10.1080/01419870701599465

Wall Street Journal (2018). 28 ${ }^{\text {th }}$ December 2018, 'Teachers Quit Jobs at Highest Rate on Record', available at: https://www.wsj.com/articles/teachers-quit-jobs-at-highest-rate-on-record-11545993052

Washington Post (2017). Where have all the teachers gone? Available at: https://www.washingtonpost.com/news/answer-sheet/wp/2017/09/18/where-have-all-the-teachers-gone/?noredirect $=$ on\&utm_term $=$. ab5877654c3e

We are Teachers (2018). Why Teachers Quit, available at: https://www.weareteachers.com/why-teachers-quit-the-profession/

Wellspring foundation (2018). Rise to Shine, available at: http://thewellspringfoundation.org/stories/rise-to-shine/

Why Teach (2015). website, available at:

http://whyteach.lkmco.org/wp-content/uploads/2015/10/Embargoed-until-Friday-23-October-2015-Why-Teach.pdf

\section{Copyrights}

Copyright for this article is retained by the author(s), with first publication rights granted to the journal.

This is an open-access article distributed under the terms and conditions of the Creative Commons Attribution license which permits unrestricted use, distribution, and reproduction in any medium, provided the original work is properly cited. 